\title{
VALIDATION OF TWO TAXON NAMES IN EUGLENA (EUGLENOPHYTA)
}

\author{
KONRAD WOŁOWSKI
}

Konrad Wolowski, Department of Phycology, W. Szafer Institute of Botany, Polish Academy of Sciences, Lubicz 46, $31-512$ Kraków, Poland; e-mail: k.wolowski@botany.pl

During completion of a list of new taxa of euglenophytes described by scientific workers of the Institute of Botany of the Polish Academy of Sciences I found that two names of taxa of Euglena C. G. Ehrenberg were invalidly published because the types were not indicated. In order to fulfil the requirements of Art. 40.5 of ICN (McNeill et al. 2012) these names are validated herein.

\section{Euglena ettlii Wołowski, sp. nov.}

Euglena ettlii Wołowski, Arch. Protistenk. 143: 173176. 1993, nom. inval. typ. non indic.

TYPE CITATION: POLAND. WYŻYNA KRAKOWSKOCZĘSTOCHOWSKA UPLAND. Bębło near Cracow, shallow village pond, 14 March 1990, leg. K. Wołowski. HoLOTYPE: Figure 1 in Wołowski, Archiv. Protistenk. 143: 174. 1993.

NoTE. For detailed description, illustrations and discussion see Wołowski (1993).

Euglena rustica Schiller fo. maior Wołowski, fo. nov.

Euglena rustica Schiller fo. maior Wołowski, Fragm. Florist. Geobot. 33(1-2): 220, Figs 4a-e, Photo 1, nom. inval. typ. non indic.

TYPE CITATION: POLAND. Kraków. Sewage treatment plant of the Kliny Housing development, small concrete reservoir surrounding base arm of rotatory trickling filter, January 1979 to May 1980, leg. K. Wołowski. HolotyPe: Photo No. 1 in Wołowski, Fragm. Florist. Geobot. 33: 220. 1988.

NoTE. For detailed description, illustrations and discussion see Wołowski (1988).

ACKNOWLEDGEMENTS. I am grateful to Professor Ryszard Ochyra for helpful suggestions. This research received support from the statutory funds of the Institute of Botany of the Polish Academy of Sciences (Kraków, Poland).

\section{REFERENCES}

McNeill J., BARrie F. R., BuCK W. R., DemOUlin V., GReUTER W., HAWKSWORTH D. L., HERENDEEN P. S., KNAPP S., Marhold K., Prado J., Prud'homme van Reine W. F., Smith G. F., Wiersema J. H. \& Turland N. J. 2012. International Code of Nomenclature for algae, fungi and plants (Melbourne Code) adopted by the Eighteenth International Botanical Congress Melbourne, Australia, July 2011. Regnum Veg. 154: 1-240.

WOŁOWSKI K. 1988. Euglenophyta from the sewage treatment plant of the Kliny housing development in Cracow. Fragm. Florist. Geobot. 33(1-2): 217-226.

WoŁowsKi K. 1993. Euglena ettliii Wołowski sp. nova (Euglenophyceae). Arch. Protistenk. 143: 173-178. 